\title{
Hate Speech or Genocidal Discourse? An Examination of Anti-Roma Sentiment in Contemporary Europe
}

\section{Emma Townsend, University of Queensland}

\begin{abstract}
The final solution to the Gypsy question proposed by the National Party is a blueprint for all European states ... STOP! their demanding and thieving mentality ... We don't want parasites among us ... We protect you and your family. (National Party quoted in Albert 2012: 139-140)
\end{abstract}

The above proposition for a 'final solution to the Gypsy question,' strongly reminiscent of Nazi genocidal propaganda, was made during the 2009 European Parliament elections in the Czech Republic by the far-right National Party (Albert 2012: 139). This statement is symptomatic of the pervasive negative attitudes present in many European states towards members of the Romani community. Physical persecution of Roma is also common, often manifested in racially motivated violence that is frequently ignored and occasionally encouraged by state authorities (Amnesty International 2011:4-5; Council of Europe 2012: 39-40,64; Stewart 2012: xiii-xix). This context of persecution, exclusion, and stigmatisation is informed by a discourse that renders some extremely negative actions largely acceptable, such as the segregation of Roma into villages (and often ghettos) enclosed by walls or monitored by guards and video cameras (Amaré 2010; Hollinger 2010; Council of Europe 2012: 93-99). The stigmatisation of Roma (as well as their persecution and exclusion) in contemporary European states has been widely recognised and discussed. ${ }^{1}$ It is questionable, however, if previous approaches have been adequate to explain the nature of the discourse present in many European states towards Romani people.

\footnotetext{
${ }^{1}$ See: Amnesty International (2011); Centre for Reproductive Rights and Poradňa pre obcianske a l'udské práva (Centre for Civil and Human Rights) (2003); Council of Europe (2012); Halász (2008); Hancock (2002); Nicolae (2002); Scicluna (2007); Sigona (2005, 2011); Stewart (2012).

PORTAL Journal of Multidisciplinary International Studies, vol. 11, no. 1, January 2014. Stigma and Exclusion in Cross-Cultural Contexts Special Issue, guest edited by Annie Pohlman, Sol Rojas-Lizana and Maryam Jamarani. 
In this article, I utilise the concept of genocidal discourse to analyse instances of negative language used in relation to Romani communities in contemporary Europe. In this analysis, I question whether some of the persecutory actions taken towards Roma by a number of contemporary European states are informed by a discourse that is not simply stigmatising, but can be understood as genocidal discourse. I preface this analysis with an examination of the origins and history of Romani populations, along with an outline of their contemporary treatment. This historical and contextual discussion provides a brief overview of the situation within which potential instances of genocidal discourse must be located. I then discuss the concept of genocidal discourse in relation to its place within the continuum of group-targeted negative language. I analyse three examples of Roma-targeted extreme negative speech in three different states. Through these examples, I argue that there is a genocidal discourse in European states targeted at Romani people and communities. Further, these examples will reveal the influence that this discourse has in shaping actions towards Roma, particularly with regard to exclusionist policies. Both the presence of a genocidal discourse and the influence this discourse has on informing actions towards Roma are significant findings with considerable implications for contemporary European states.

I examine genocidal discourse as a pan-European phenomenon. As such, this article is intended to provide a broad overview of the negative language used towards Roma as a phenomenon not confined by state borders. It is thereby intended to compliment analyses of similar language and/or exclusion that are state-specific, as exemplified in the work of scholars such as Kelso (2007, 2013), Magyari-Vincze (2006a, 2006b), Sigona $(2005,2011)$ and Woodcock $(2007 a, 2007 b)$. This approach consequently conceptualises the discourse present in different European states as individual manifestations of a wider trend. ${ }^{2}$ Sigona's work on the Italian response to Roma through placement in 'nomad camps' (2005, 2011), Magyari-Vincze's studies on ethnicallymotivated discrimination affecting the reproductive health of Romani women in Romania (2006a, 2006b), and the work of both Kelso $(2007,2013)$ and Woodcock (2007a, 2007b) on the conflicts in Romania over both identities and genocide

\footnotetext{
${ }^{2}$ A similar contention has been made by Polak, who in an article examining the challenges of teaching about the Romani genocide during World War II in Europe, argued 'The history and contemporary situation in Romania is very different from other countries in Europe but the influence of negative attitudes to Roma on the willingness to teach about their history ... has been voiced by colleagues working in the field of Holocaust education across Europe' (2013: 80).
} 
recognition demonstrate the diversity of the treatment of Roma in individual European states. Approaching this issue as a pan-European phenomenon is not to deny that the context and history of each European state is unique; nor does it deny the specificity of many state responses towards Roma. Rather, my pan-European approach recognises that the treatment of and discourse towards Roma - a transnational and pan-European minority group - in individual European states cannot be understood (or challenged) without understanding and acknowledging the wider context. This approach therefore offers the chance to identify, understand, and challenge wider European trends that may resist positive change when only discussed at the individual-state level.

\section{Methodology and terminology}

Genocide is both an emotive and contested concept. As argued by Powell in his examination of how civilisations produce genocide, 'Almost every scholar who writes about genocide proposes his or her own definition' (2011: 60). One definition of particular significance is found in the United Nations Convention on the Prevention and Punishment of the Crime of Genocide (UNCG). The convention criminalises genocide and allows for prosecution of its perpetrators (United Nations 1948: 280). The value in the criminalisation of genocide is clear. However, there is also value in engaging with sociological perspectives on the concept of genocide. This approach emphasises the importance of understanding what happened - genocide - and how and why that genocide occurred (Powell 2011: 59). In arguing for the value of a sociological understanding of genocide, Powell contends that while the findings of such an examination may be complex, 'we need to face these complexities and confusions if we hope to find ways to prevent genocide rather than to punish it after the fact' (2011: 59). This article similarly engages with genocide—or, more specifically, genocidal discourse - as a sociological concept, and accordingly refrains from analysis of the concept's legal uses or implications.

This discussion must also be prefaced with a note on terminology, which plays a significant role in any discussion of Roma. Many of the names used to refer to Roma are born of prejudice or misunderstanding (Gheorghe and Liégeois 1995: 7). The term 'Roma' is deliberately used here and refers to all those who identify themselves as Roma, 'Sinti,' 'Travellers,' 'Gypsies,' 'Cale/Kale,' 'Romanichel' or 'Manouches,' among others (Hübschmannova 2003: 2-3). 'Rom' is the term most Roma groups use 
themselves, of which 'Roma' is the plural form (Amnesty International 2011: 3; Gheorghe \& Liégeois 1995: 8). The use of the term 'gypsy/Gypsy' is no longer appropriate, given that it was based on the mistaken belief that Roma were Egyptian in origin (Hancock 2002: xxi). Likewise, the various contemporary names used that originate from the Ancient Greek 'Atsinganos' are inappropriate; this name meant 'untouched/untouchable' and is therefore highly (though often unknowingly) stigmatising (Gheorghe \& Liégeois 1995: 7). I therefore deliberately use the term Roma for these reasons.

\section{Romani history in Europe}

The Roma are the largest minority group in contemporary Europe (Amnesty International 2011: 3; Council of Europe 2012: 11). Despite a lack of accurate data, it is estimated that there are 10 to 12 million Roma in Europe, and this population is transnational, non-territorial, and extremely heterogeneous (Amnesty International 2011: 3; European Association for the Defense of Human Rights 2012: 7; Gil-Robles 2006: 4; Petrova 2003: 114). The exclusion, persecution and stigmatisation of Roma commenced almost immediately upon their arrival in Europe. The Romani people originated in India and migrated west for unknown reasons, with records indicating that the first arrivals in Europe occurred in the thirteenth century (McGarry 2010: 10). By the fifteenth and sixteenth centuries Roma were present across Europe (Fraser 1995: 85-122; Gheorghe \& Liégeois 1995: 7). Claims of witchcraft, thievery and espionage were frequently levelled against Roma (Barany 2002: 89; Fraser 1995: 75, 89; McGarry 2010: 10-12). From the sixteenth century, countries such as Denmark, England, France, Germany, Italy, the Netherlands, Norway, Scotland, Sweden, and Switzerland passed various laws that made it illegal—often under threat of death—for Roma to cross their borders (Fraser 1995: 131; Liégeois 1994: 125-130; Petrova 2003: 123-124).

Additionally, Roma were widely used as slaves in the territory that is present day Romania for centuries, with this practice abolished only in 1864 (Hancock 2002: 18-25).

One of the most widely held and influential stereotypes of Roma has been that of a 'biological' nomadism (Hancock 2002: 101; Mayall 2004: 130, 133; McGarry 2010: 8; Petrova 2003: 120). Nomadism came to be almost synonymous with Romani culture and was routinely outlawed (Kenrick \& Puxon 1972: 50; Mayall 2004: 130, 252). This myth has shaped many of the interactions by mainstream European society with Roma. 
This was particularly true as the socioeconomic landscape in Europe designated nomadism as neither economically useful nor socially acceptable behaviour (Petrova 2003: 124, 129). Despite this enduring stereotype, it is clear that nomadism was (and still is) partially or even largely a reactionary behaviour developed by Romani communities in response to economic considerations, enduring persecution, and the difficulties faced in accessing the same rights as other citizens (Crowe 2003: 91; Fraser 1995: 43; Gheorghe \& Liégeois 1995: 7; Hancock 2002: 101; Liégeois 1994: 27). The endurance and influence of the nomadic myth makes clear the impact that language and perceptions of Roma have had on their treatment and in determining what actions are 'acceptable' in contemporary Europe.

Along with the nomadic myth, other negative perceptions of Roma have been influential, notably the enduring, negative and powerful stereotypes of Roma as 'dirty,' 'thieves,' 'dangerous' and 'inferior' (Gheorghe \& Liégeois 1995: 8-9; Hammarberg 2008). With the rise of ideas of race and race science in the nineteenth century, such perceptions assumed fixed biological overtones (Fings, Heuss \& Sparing 1997: 19; Hancock 1999: 45, 47, 2002: 35; Mayall 2004: 89). This racial discourse, seized upon by the Nazis in the 1930s, justified the large scale genocide of Roma alongside the many other victims of Nazism during the Holocaust (Huttenbach 1991: 31-33). It is unclear precisely how many Roma were murdered during this genocide; many deaths occurred outside the organised structure of concentration camps and thus went unrecorded, and pre-war population figures were incomplete (Hancock 2002: 46-47; United States Holocaust Memorial Museum 2001). The most widely accepted estimates place the number of deaths in the range of 250,000-500,000 (Amnesty International 2011: 4; Fraser 1995: 268; Huttenbach 1991: 45; Kelso 2007: 47, 2013: 63; Liégeois 1994: 134; Polak 2013: 82). ${ }^{3}$ This period in European history again demonstrates the importance of perceptions and language in informing what actions are seen as 'acceptable' and 'legitimate' for Romani people.

Despite the substantial evidence indicating that this genocide was motivated by ideas of an inferior Romani 'race,' the genocide of Roma during WWII was denied by many states until recently, with Germany only officially recognising the Romani experience

\footnotetext{
${ }^{3}$ A number of scholars estimate the number of deaths were far higher: Hancock provides estimates of 500,000-1,500,000 (2002: 48); McGarry similarly estimates 250,000-1,500,000 Roma were killed (2010: 20) - and Nicolae suggests that 250,000-1,000,000 Roma were murdered during WWII (2002: 66).
} 
during the Holocaust as genocide in 1982 (Sridhar 2006: 3571; United States Holocaust Memorial Museum 2011; Wippermann 2006: 175). An official memorial for the Romani Holocaust, referred to by some scholars as 'Porajmos' (devouring) or 'Samudaripen' (murder of all), was inaugurated in Berlin only in 2012 (Evans 2012; Polak 2013: 79, 82). This belated historical recognition of genocide has contributed to the contemporary environment in which the persecution of Roma continues. ${ }^{4}$ Their past genocide has not been widely acknowledged, and consequently the links with their contemporary treatment are not made - whether these links are identified in the language used in reference to Roma, or in the policies and actions that target Romani populations.

Serious persecution of Roma has continued throughout the post-WWII period, arguably at least partially as a result of the lack of recognition of the Romani genocide. One of the most egregious examples of genocidal intent towards Roma in post-war Europe is identifiable in the numerous instances of coercive and forced sterilisations of Romani women and girls (European Association for the Defense of Human Rights 2012: 15). State run programs of involuntary sterilisation existed in Norway from 1934 to 1974, Sweden from 1935 to 1975, and in Switzerland from the 1920s through to the 1980s (Scicluna 2007; Staff of the U.S. Commission on Security and Cooperation in Europe 2006: 4). A frequently coercive sterilisation program was also run in Czechoslovakia beginning in 1967 and enduring through the break-up of the state, with cases alleged as recently as 2009 (JUDr. Otakar Motejl: Public Defender of Rights 2005: 26; Open Society Foundations 2011: 3; Thomas 2006). These sterilisation practices confirm that a stigmatising view of Roma endured largely uninterrupted in the post-WWII period. The perceptions of Romani people as 'inferior,' 'unhealthy' and as a 'threat' to states that justified their genocide in Nazi Germany continued to be perpetuated (Albert 2011: 2; Helsinki Watch 1992: 21-21, 28-29). This language has very strong parallels with that

\footnotetext{
${ }^{4}$ A growing body of scholarship challenges the exclusion of Roma from Holocaust studies and remembrance with scholars, Romani activists, and genocide survivors and their families all contributing to the powerful movement for recognition and remembrance. For example, Hancock (2002), Kelso (2007, 2013), Polak (2013), and Woodcock (2007b), have and continue to produce work challenging the historical denial of recognition. However, this article is focused on the actions, constructs, and opinions of the non-Romani majority towards the Romani minority; therefore the historical denial and silencing of the Romani genocide is significant as the majority European consciousness does not necessarily reflect the work of scholars and activists. For example, Kelso reports that 'History and civic teachers across [Romania] told me that they knew almost nothing about the Holocaust history of Roma' (2013: 66).
} 
used to justify the genocide of Roma in Nazi Germany, demonstrating a continuity of a potentially genocidal discourse within a wider context of ongoing persecution.

The persecution, exclusion and stigmatisation of Roma intensified across Europe in the 1990s in the aftermath of the collapse of communism, the expansion of the European Union, and the resulting economic, political and societal changes (Amnesty International 2011: 4-5; Brearley 2001: 591; Fraser 1995: 289-290; Liégeois 1994: 155; O’Nions 2011: 373; Stewart 2012: xvi). The particular persecution of Roma during this period has been noted by the Organization for Security and Co-operation in Europe, which in a report published in 2000 argued that:

\begin{abstract}
Even against the backcloth of a decade blighted by extreme forms of racist intolerance, the phenomenon of prejudice against Roma is singular. Romani communities are the subject of hostile perceptions across an extraordinary range of countries. In some, politicians and citizens feel few scruples about expressing derogatory stereotypes of Roma. In this climate, Roma have been prime targets of skinhead violence and, at times, what must properly be called pogroms. (Van der Stoel 2000: 3 )
\end{abstract}

The proposition that 'the phenomenon of prejudice against the Roma is singular' is significant: it asserts that the persecution of Roma was (and is) not simply symptomatic of a changing economic and political landscape. Likewise, it cannot be equated with the reactions of many states towards migrants and outsiders in similar periods. The persecution of the Roma in contemporary Europe can and should be placed in a category of its own.

\title{
Exclusion and stigmatisation in the contemporary period
}

The contemporary period (from 2000 to the present day), on which this article focuses, has seen no abatement in the persecution of Roma or the negative language used in reference to them. Roma are stigmatised and excluded on a regular basis and are also frequently made targets of racially motivated violence (Council of Europe 2012: 3940,63-64; Stewart 2012: xiii-xix). In his book examining the increasing anti-Roma sentiment in Europe in recent years, Stewart quotes the mayor of a Hungarian village as saying:

I just don't understand this question about who is a Gypsy. It is quite clear, isn't it? Everyone who is a Gypsy is a Gypsy. You can smell them from a kilometre. There is no definition for this- I can't find one. You have to accept that a person who was born a Gypsy has a different temperament; they live differently and behave differently. I grew up among Gypsy children. Everyone who is a Gypsy has remained a Gypsy. It makes no difference if they have a bath every night, the smell remains, just like with horses. There is a specific Gypsy smell. (2012: xviii) 
Similar attitudes can be identified in Romania; the mayor of the town of Craiova was quoted in 2005 as saying that 'if I put them [Roma] in the zoo and showed them to kids saying look at the monkeys, they wouldn't see any difference' (Scicluna 2007). The two statements indicate the acceptability of the stigmatisation of Roma in contemporary Europe.

In an examination of negative language and hate speech, the political philosopher Bhikhu Parekh argued that 'if anything can be said about a group of persons with impunity, anything can also be done to it' (Parekh 2006: 218). The relationship between speech and action is significant, as racially motivated violence targeting Roma has occurred across Europe with methods ranging from assaults to arson and fire bombings (Council of Europe 2012: 63-64; Stewart 2012: xiv-xvi). Such incidents are regularly denied sincere investigation by authorities (Council of Europe 2012: 64; Stewart 2012: xiv-xvi). In a survey conducted in 2008, 18 percent of Romani people questioned reported that they had been targeted by racially motivated violence in the preceding year (European Union Agency for Fundamental Rights 2009: 9). Such incidents of racially motivated violence cannot be understood — and therefore prevented—without contextualising them as physical manifestations of stigmatising speech.

The influence of negative speech can also be observed in the violent exclusion of Roma from majority European societies through official policies and actions. For example, in 1999, a wall was constructed in the Czech town of Usti nad Labem, with the Mayor stating that 'this wall is about one group that obeys the laws of the Czech Republic and behaves according to good morals, and about a group that breaks these rules - doesn't pay rent, doesn't use proper hygiene and doesn't do anything right' (quoted in Perlez 1998). In Ostrovany in Slovakia in 2009, another wall was built ostensibly to protect the non-Roma residents and to prevent Roma 'from entering private gardens and stealing' (Cyril Revak quoted in Bednarikova 2009). In 2011 in the town of Baia Mare, Romania, a wall was built between the Roma and non-Roma to maintain 'order and discipline' (Catalin Chereches quoted in Lacatus 2011). This exclusion only deepened when in June 2012, the Romani community was moved from their walled ghetto in Baia Mare to accommodation in a decommissioned chemical factory (Lacatus 2012). Within days, signs of poisoning were shown by both children and adults (Lacatus 2012). The justifications offered for such acts of extreme physical exclusion-as well as the 
occurrence of such acts in and of themselves - typify the widespread negative discourse that targets Roma. This discourse has the potential to legitimise extreme acts of violence and physical exclusion as the only viable course of action in the face of such a 'threat.'

\section{Genocidal discourse and negative language}

The Holocaust did not begin in the gas chambers; it began with words. These are the catastrophic effects of racism (Cotler 2011: 132).

Genocidal discourse, as I call the form of discourse identified above, is a form of negative, group-targeted language. It can be situated within a set of concepts that refer to the virulent and often violent language used to stigmatise and denigrate a people belonging to a 'group.' The concept of genocidal discourse is rarely defined; however, its meaning can be inferred through the definition of the term 'genocide.' Genocide refers to the intentional targeting of a group for destruction as defined in the United Nations Convention on the Prevention and Punishment of the Crime of Genocide (UNCG):

Any of the following acts committed with intent to destroy, in whole or in part, a national, ethnical, racial or religious group, as such:

(a) Killing members of the group;

(b) Causing serious bodily or mental harm to members of the group;

(c) Deliberately inflicting on the group conditions of life calculated to bring about its physical destruction in whole or in part;

(d) Imposing measures intended to prevent births within the group;

(e) Forcibly transferring children of the group to another group (United Nations 1948: 280)

Accordingly, a genocidal discourse refers to a widely used and accepted language of negation, destruction and erasure targeted at a particular group or groups. While other forms of negative language that target Roma are heard in Europe, Roma are frequently the targets (and victims) of a discourse that legitimises a genocidal end-goal - the erasure, removal or destruction of the Romani group — but that does not necessarily encourage or incite a genocidal process. ${ }^{5}$ The adequacy of genocidal discourse will become clear through my analysis of the concepts of hate speech, genocidal discourse, and incitement to genocide, with all three concepts being located along what could be termed a 'negative language continuum.'

\footnotetext{
${ }^{5}$ For example, Nicolae has repeatedly identified hate speech targeted at Roma $(2002,2005,2009)$. Other scholars have examined how labels and stereotypes (often negative) ascribed to Roma by non-Roma in a number of European states are purposively utilised and engaged with by both non-Roma and Roma: see Sigona $(2005,2011)$ and Woodcock $(2007 \mathrm{a}, 2007 \mathrm{~b})$.
} 
A number of authors have examined the various categories of negative language, some of whom have also elaborated on some form of a continuum of language (Benesch 2007-2008, 2011a, 2011b, 2012; Cotler 2011; Cryer 2005; Parekh 2006; Timmermann 2008; Wallenstein 2001). Within this scholarship, hate speech is a widely analysed and contested concept (Benesch 2007-2008, 2011b, 2012; Parekh 2006; Timmermann 2008). Benesch defines hate speech as 'a very broad category including (1) speech that is intended to harm directly, by insulting or offending the person or people it purports to describe; and (2) speech intended to cause indirect harm, by inciting one person or group against another' (2011b: 390). Benesch also makes clear that hate speech 'denigrates people on the basis of their membership in a group' (2012: 1). Timmermann likewise conceptualises hate speech as a form of language that stigmatises, demonises and humiliates a group, resulting in the targeted group experiencing 'utter helplessness and lack of control' (2008: 359). According to such conceptualisations, hate speech is the public expression of hate. This hate can and does harm; however, it is not necessarily intended to cause action and it does not promote group destruction.

Parekh argues for a more extreme conceptualisation of hate speech:

\footnotetext{
Hate speech expresses, advocates, encourages, promotes or incites hatred of a group of individuals distinguished by a particular feature or set of features. Hatred is not the same as a lack of respect or even positive disrespect, dislike, disapproval, or a demeaning view of others. It implies hostility, rejection, a wish to harm or destroy, a desire to get the target group out of one's way, a silent or vocal and a passive or active declaration of war against it. (2006: 214, emphasis mine)
}

In Parekh's conceptualisation hate speech exceeds the boundaries of hate, for to hate a group and to desire its erasure or destruction are different sentiments. A desire for group destruction is essentially genocidal in nature and reflects a far greater hostility than 'hate.' The sentiments contained in Parekh's conceptualisation are therefore closer to genocidal discourse or incitement to genocide, as they either use the language of or suggest acts that pursue a goal of group destruction. Hate speech is the verbal expression of hostility, vilification, denigration and stigmatisation. It is a necessary condition for further radicalisation of negative language; without the denigration and stigmatisation of a group, justifying their destruction could not occur:

An exploration of the thought processes and emotions of those who have committed hate crimes and been actively involved in mass atrocities reveals how the stigmatization of the victims and their exclusion from the human community enabled the perpetrators to engage in these acts while simultaneously remaining convinced that these acts were necessary and, in fact, corresponded to what the prevailing morality required of them. (Timmermann 2008: 359) 
Cotler concurs, arguing that:

The enduring lesson of the Holocaust and the genocides that followed, from Srebrenica to Rwanda, was that they occurred not only because of the machinery of death, but because of the statesanctioned incitement to hate. It was this teaching of contempt, this demonizing of the other; this is where it all began. (Cotler 2011: 131)

Hate speech therefore plays a vital role in making possible a radicalisation of hate into justified destruction, and its importance in creating a context of violent hatred that can be used to legitimise physical actions cannot be understated. It does not, however, justify destruction or necessarily suggest any kind of physical action in and of itself. As such it is located at the least extreme end of the negative language continuum.

At the opposite end of the negative language continuum is incitement to genocide. Incitement refers to 'an attempt to persuade another person, by whatever means, to commit an offense,' in this case, genocide (Cryer 2005: 493). Therefore, incitement to genocide refers to speech that does not simply call for group destruction, but that is likely to or capable of provoking individuals or groups to commit violent acts intended to destroy the target (victim) group. Further, incitement to genocide is included in the UNCG as a crime alongside genocide, conspiracy to commit genocide, attempt to commit genocide, and complicity in genocide (United Nations 1948: 280). In order for a speech or any other form of expression to fall under the rubric of incitement to genocide, a number of preconditions must be met. Benesch lists the indicators necessary for speech to be categorised as incitement to genocide, which focus on the context in which the incitement occurred (for example, previous violence and psychological conditioning) and the receptiveness of the audience to the incitement (2007-2008: 498). Cryer similarly contends that for incitement to have occurred and to be prosecutable, it must have been public, direct (particularly as understood within its context), and the expression of the inciter's own desire for the target group to be destroyed (2005: 500). Wallenstein likewise engages with the concept of incitement to genocide, arguing for the centrality of intent: 'incitement cannot be accidental; it must be coordinated and dispersed by those with a broader plan of destruction of a people' (2001: 388). The above criteria make clear that incitement to genocide is the purposeful, direct, and public call for the destruction of a group, made to a receptive audience within a context already primed for the hatred, delegitimisation and rejection of the target group. This form of negative language is intended to provoke a physical manifestation of the violent 
sentiment being expressed. Incitement to genocide cannot be identified (or, more specifically, prosecuted) without the presence of an audience. It is therefore situated at the far end of the negative language continuum. That said, neither hate speech nor incitement to genocide encapsulate the contemporary situation in which Roma are denigrated and vilified without being the target of widespread calls for physical genocide. Rather, they are the targets (and victims) of a discourse that uses a language of negation, erasure and destruction.

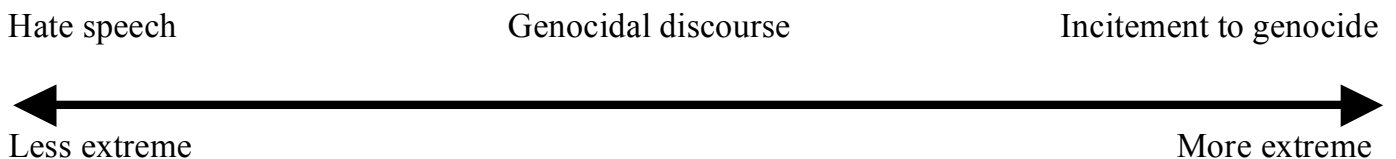

Figure 1: The negative language continuum.

As already noted, the most adequate and useful concept that encapsulates the true nature of this language is genocidal discourse. On the negative language continuum, genocidal discourse is a more extreme form of negative language than hate speech. Genocidal discourse involves the escalation of a widely acceptable language of hatred into language that proposes, promotes or justifies the destruction of a group as acceptable and/or necessary. Such calls for destruction do not necessarily have to be located within a plan for destruction or a call for people to cause this destruction. The identification of a genocidal discourse is not dependent on a receptive audience. For this reason genocidal discourse is a less extreme form of negative language than incitement to genocide on the negative language continuum. It must be noted, however, that while physical violence may not occur as a result of genocidal discourse, its use has consequences, and national policies toward and state treatment of Roma can be informed by its presence. Further, genocidal discourse has the potential to escalate into incitement to genocide, which is both a crime as defined in the UNCG and a clear indicator that genocide could occur (Benesch 2007-2008: 488, 493). Despite the frequent confluence of the different forms of negative language, the concept of genocidal discourse helps to explain some of the language used in contemporary Europe.

\section{Genocidal discourse in contemporary Europe}

Czech Republic and geographical erasure-National Party and Workers' Party

One of the most overt and public manifestations of genocidal discourse directed at 
Roma in contemporary Europe has been expressed by the Czech National Party (NP). In 2009 in its campaign for election to the European Parliament the National Party produced a television advertisement that explicitly utilised a genocidal discourse against Roma (Albert 2012: 139). The advertisement opened with a depiction of a flock of white sheep literally kicking a black sheep off the Czech Flag (National Party 2009). As the advertisement progresses it becomes clear that this scene is intended to depict 'white sheep' Czech citizens 'kicking out' the Romani 'black sheep.' The next screen states that 'the final solution to the Gypsy question proposed by the National Party is a blueprint for all European states' (Albert 2012: 139). This 'final solution blueprint' involves the deportation of all Roma 'back' to India — a country that the Romani people migrated from centuries earlier (Albert 2012: 140). The advertisement continues by making the following statements: 'Stop black racism,' 'National Party against integration of inadaptables,' 'No! Favouring of Gypsies,' 'We defend Czech national interests,' 'Stop! their demanding and thieving mentality,' 'Your taxes - their future!,' and 'We do not want black racists among us' (Albert 2012: 139-140). The advertisement concludes with the statement, 'we don't want parasites among us,' and the NP claim that 'we protect you and your family' (Albert 2012: 139-140). The NP election advertisement was aired briefly on the public station Czech Television, and was subsequently placed on YouTube after being pulled from the station (Albert 2012: 140). Once on YouTube, many supportive comments were made of the advertisement and the sentiments it espoused, including the claim that 'the Roma are the cancer of the Czech Republic' (Albert 2012: 140).

During this period, the Czech Workers' Party (WP) organised 'protection corps' of uniformed party members to 'monitor' Romani neighbourhoods (Albert 2012: 141). This action was allegedly taken in response to complaints made against Romani communities by 'decent' (read non-Romani) citizens that had not been addressed by police (Albert 2012: 141). The WP claimed, as did the NP in its advertisement, that majority Czech society is the victim of 'black' (Roma) racism, but that the party itself is not racist (Albert 2012: 142-143). Albert argues that such claims are symptomatic of a wider trend in Czech society by which "the non-Roma "majority society," which has the power to exclude the Roma and has done so for generations, views itself as the victims of those it excludes, and attempts to usurp the rhetoric of rights to justify its behaviour' (Albert 2012: 143). 
The two incidents in the Czech Republic from 2008-2009 indicate how genocidal discourse towards and about the Romani people may be expressed by those with some degree of public influence. In this discourse, Roma are thieves, drains on the state and hardworking tax payers, parasites, and ultimately present such a threat to the Czech state that a 'final solution' must be found to the 'problem' they embody. Clear parallels are evident between this language and the genocidal discourse used in Nazi Germany towards Roma, along with Jewish and other peoples. Thomas Hammarberg, the 20062012 Council of Europe Commissioner for Human Rights, noted this parallel:

Today's rhetoric against the Roma is very similar to the one used by Nazis and fascists before the mass killings started in the thirties and forties. Once more, it is argued that the Roma is a threat to safety and public health. No distinction is made between a few criminals and the overwhelming majority of the Roma population. This is shameful and dangerous. (Hammarberg 2008)

Indeed, the NP articulates a genocidal discourse of erasure of Roma through the proposed deportation of Roma from 'all European states.' In the NP advertisement, Roma are the victims of an unambiguous plan for group-targeted geographical erasure.

Both the WP and the NP were far-right extremist parties (Albert 2012: 138) that received a very small percentage of votes in European Parliament elections - in 2009 the WP received 1.07 percent of the vote, the NP a mere 0.26 percent (Albert 2012: 153-154). Despite these poor polling results, the influence of the rhetoric used by the parties should not be understated (Albert 2012: 138). Albert argues that the language used and actions taken by the two parties reflect the deep anti-Romani sentiments in Czech society, and are not isolated manifestations of extremism (Albert 2012: 138). A 2012 poll showed that 71 percent, or almost three quarters of the Czech population, held a negative view of Romani people (Bikár 2012). ${ }^{6}$ These opinions range from somewhat negative (34 percent), to unequivocally negative (26 percent), with 10 percent of respondents claiming they 'loathe' Roma (Bikár 2012). Only 5 percent of respondents reported having a good or very good opinion of Roma in the Czech Republic (Bikár 2012). A 2013 poll conducted by the same agency found that negative attitudes towards Roma have remained stable, despite an increase in the tolerance for the right of minority groups generally to live according to their cultural values (Czech Press Agency 2013). ${ }^{7}$

\footnotetext{
${ }^{6}$ This poll was conducted by the STEM agency among a representative sample of 1062 Czech residents from 27 October to 5 November 2012, with the respondents chosen by the quota selection method (Bikár 2012).

${ }^{7} 1000$ respondents were polled by STEM between 2 and 9 April 2013 (Czech Press Agency 2013).
} 
Even when informed by no personal experience, the perceptions of Roma held by many Czechs remain generally negative: 'In the absence of direct personal experience, nonRoma relate claims of Romany transgressions to other non-Roma for which they are usually unable to offer proof (even if the claims defy reason)' (Albert 2012: 144). In the anti-Romani environment spurred on by the public expression of genocidal discourse, riots, public anti-Roma demonstrations, and arson attacks targeting Roma have occurred in recent years. In one instance, a Romani family threatened with murder were denied assistance by the police: 'when they called the authorities for help, they were told either to barricade themselves in their home and call the police if someone tried to break in, or to leave town' (Albert 2012: 161). The wide anti-Romani sentiment in the Czech Republic provides the backdrop against which more extreme deployments of genocidal discourse, typified by the two rightwing political parties discussed above, can take place. Thus, the securitising of Roma as a physical threat to the state that demands monitoring clearly becomes legitimated and even expected in a state where Romani people are the targets of an acceptable and often explicit genocidal discourse.

\section{France and geographical erasure}

A Romani-targeted genocidal discourse is also identifiable in contemporary France, which is epitomised in a statement made by Francois Hollande in 2012 during his Presidential campaign (Glenny 2012: viii). While still a Presidential candidate, Hollande stated that 'the origin of the problem, that is to say the movement of a population that is nowhere accepted and lives in abject conditions, is that we did not establish a European regulation (une règle européenne) to keep that population where it ought to live, in Romania' (quoted in Glenny 2012: viii). The statement must be situated within a climate of high tensions between Roma and non-Roma in France, particularly due to the strong association in the country between Roma and crime (About 2012: 95-96; Council of Europe 2012: 41). Hollande made this call for a Europe-wide regulation on the Romani 'problem' when he was a Presidential candidate in an election that he went on to win. As such, his comments appeared to be acceptable and legitimate to the general French public, and thus can be understood as representative of a wider antiRoma discourse that promotes the geographic erasure and destruction of the Romani group. Hollande does not call for Roma to 'change,' to be integrated, or to be accepted. Rather, his statement makes clear that the best 'solution' to the Romani 'problem' is to remove them entirely from France, and from most other European countries, in what 
amounts to another example of how genocidal discourse in contemporary Europe towards Roma is played out.

Parallelling the genocidal discourse in the public domain against Roma in France have been such state-sponsored actions as the expulsions of Roma that began under the Sarkozy government in the summer of 2010. Roma were widely targeted for collective eviction and expulsion, with a cash payment of $€ 300$ offered to any Roma who 'volunteered' to leave (Council of Europe 2012: 204; O'Nions 2011: 380). While the French government denied that Roma were the specific targets of this policy, an August 2010 presidential circular stated that Roma camps should be prioritised for eviction (About 2012: 95-99; O’Nions 2011: 380). The expulsions were not the first ethnically targeted policies of exclusion towards Roma in France; the genocidal discourse that drove them also informed other exclusionary policies dating from 2007 (Amaré 2010). This particular policy saw the creation of a village d'insertion (social insertion and/or integration village) in a Parisian prefecture after a fire destroyed a shanty-town in Aubervilliers (Amaré 2010). There are now a number of these villages in France, all of which are officially intended to ensure their (almost exclusively) Romani residents develop the skills necessary to integrate successfully into French society (Hollinger 2010). The villages guarantee all residents access to education, employment, healthcare and housing (Hollinger 2010). However, in these villages the residents are strictly monitored and controlled by the state. The villages are walled, monitored by guards and video cameras, access to the villages is stringently controlled (particularly for any 'outsiders') and curfews are regularly enforced for residents (Amaré 2010; Hollinger 2010). Under an allegedly benevolent guise, such villages are a physical manifestation of the same sentiment of geographical erasure on a continental scale expressed by Francois Hollande in 2012. The genocidal discourse aimed at geographical erasure in France has been influential in underwriting exclusionary actions and policies that are supported both by French authorities and majority French society.

\section{Slovakia and biological erasure}

The final example of the Romani-targeted genocidal discourse in Europe is drawn from Slovakia, where in 1995 the then Minister of Health, Lubomir Javorsky, stated that 'the government will do everything to ensure that more white children than Romani children are born' (quoted in Zoon 2001: 66). The statement exemplifies a broader national 
concern in Slovakia about the higher birth rate of the Slovakian Romani population compared to the non-Roma Slovak population (European Roma Rights Centre 2003: 10-11; Holt 2005: 927; Land 2008: 60). The key fears Javorsky was alluding to are that the Romani population will soon outnumber mainstream Slovak society and dominate the country, and that the Romani population is inherently unhealthy and inferior (Centre for Reproductive Rights and Poradňa 2003: 86; European Roma Rights Centre 2003: 10-11; Zoon 2001: 66-67).

These sentiments and the policies and actions informed by them (such as involuntary sterilisations) were also widely expressed and practiced in communist Czechoslovakia (Centre for Reproductive Rights and Poradňa 2003: 41; Council of Europe 2012: $93-$ 99). This suggests a historical continuity of anti-Roma rhetoric and policies spanning the communist and post-communist epochs. The genocidal discourse advocating the biological erasure of Roma has persisted throughout the post-communist period, as typified by a 1993 speech from then Slovak Prime Minister, Vladimir Meciar:

We ought to take into consideration ... the extended reproduction of the socially inadaptable population. Already children are giving birth to children - poorly adaptable mentally and socially, with serious health problems, who are simply a great burden on this society ... If we don't deal with them now, then they will deal with us in time. (quoted in Zoon 2001: 66)

A position paper generated by the Ministry of Health in October 2000 argued that 'if we do not succeed in integrating the Romani population and modify their reproduction[,] the percentage of nonqualified and handicapped persons in the population will increase' (Zoon 2001: 67). Also in 2000, Robert Fico, the 'leader of the Smer Party ... call[ed] for an end to "the growth of the poor quality Romani population"” (European Roma Rights Centre 2000). The examples of genocidal discourse from Slovakia are not as recent as others discussed in this article; however, they reflect a concern about the Roma that has resulted in calls for the biological erasure and destruction of at least part of the Romani communities in Slovakia. To designate a high Romani birth rate or an increased but 'inferior' Romani population a threat to the Slovak state that must be 'dealt with' is to engage with a genocidal discourse of biological erasure. Further, such statements could potentially justify specific and extreme actions that are intended to prevent future generations of Romani people in the Slovak Republic.

It is relevant to note here that while the communist era state-sponsored program of ethnically targeted sterilisation of Roma was officially abandoned in post-communist 
Slovakia, allegations of continued involuntary sterilisation of Romani women have been documented since then (Centre for Reproductive Rights and Poradňa 2003: 13-14). ${ }^{8}$

The number of Romani women involuntarily sterilised in Slovakia is unknown. A 2003

European Roma Rights Centre submission to the United Nations Human Rights

Committee detailed interviews with approximately 200 Romani women who had been involuntarily sterilised (European Roma Rights Centre 2003: 8). Another 2003 report authored by the Centre for Reproductive Rights and Poradňa interviewed 110 Romani Slovak women who either knew or strongly suspected they had been sterilised since the collapse of communism (Centre for Reproductive Rights and Poradňa 2003: 14). These numbers refer only to the women interviewed by the authors of both reports; it is highly likely that other cases exist.

While these sterilisations were not the result of official state policy, they were largely performed by doctors employed by state hospitals or state actors (Council of Europe, Commissioner for Human Rights 2003). The Slovak government has been reluctant to assume responsibility for this practice, or to express official regret (Albert 2011:2; Centre for Reproductive Rights and Poradňa 2003: 17; Zoon 2001: 65). After a number of inquiries and investigations, the Slovak government's responses have included denial that sterilisations were performed without consent (regardless of the type of consent gained), and admission that involuntary sterilisations have technically occurred but were not in violation of any rights as the sterilisations were 'medically indicated' (Centre for Reproductive Rights and Poradňa 2002: 44-48, 2003: 1-6; Council of Europe, Commissioner for Human Rights 2003; Ministry of Health of the Slovak Republic 2003). The United Nations Human Rights Committee determined in 2011 that an investigation by the Slovak government into the practice was inadequate and expressed concern 'at the narrow focus of the investigation and the lack of information on concrete measures to eliminate forced sterilisation, which, allegedly, continues to take place' (United Nations Human Rights Committee 2011: 4). Actions intended to prevent births in a particular group are potentially genocidal. For this reason, Slovak government

\footnotetext{
${ }^{8}$ Involuntary sterilisations of Romani women have also been documented in post-communist Czech Republic, where a 2004-2005 investigation carried out by the Czech Public Defender of Rights identified at least 40 Romani women who had been involuntary sterilised in the modern Czech state: see JUDr. Otakar Motejl: Public Defender of Rights (2005) and Staff of the U.S. Commission on Security and Cooperation in Europe (2006).
} 
responses to the controversy over sterilisation represent a particularly serious manifestation of the genocidal discourse in contemporary Europe towards Roma.

\section{Conclusion}

The three national examples identified in this article highlight the complex ways by which a genocidal discourse targets Roma in contemporary Europe. Roma are frequently made targets by a language of negation, erasure and destruction, with the group likewise perceived by majority populations as posing a 'threat' to the state that demands a response. The suggested — and sometimes enacted — responses to this discourse translate as physical attempts at erasure. This may involve geographical erasure, whereby the removal of Roma from the town/region/state in which they reside is advocated in an attempt to eliminate the Roma presence in the area of concern, as has happened in the Czech Republic and France. An alternative is biological erasure, the promotion of methods of population control (for example, coercive or forced sterilisations) intended to prevent the birth of future generations of Roma, as has been identified in Slovakia. In addition, physical violence against Roma is also commonplace in many European states.

The circulations of a genocidal discourse directed at the Roma in contemporary European states is significant. When the erasure of Romani people is widely legitimised through language, actions intended to achieve that goal are not merely possible but become probable. Consequently, many of the attacks on and policies toward the Roma across European states that could be seen to be persecutory or discriminatory may actually be physical manifestations of group targeted erasure. The call of 'never again' was made across Europe in the aftermath of the Holocaust - a genocide that included the Romani group amongst its victims. Recognition of the genocidal discourse targeting Roma and the potentially destructive acts that have resulted from it can potentially transform broader perceptions and treatment of Romani people. Continued misconceptualisation of the attitudes towards Roma in contemporary Europe (and the policies and behaviours informed by those attitudes) can only result in continued failure to create the conditions necessary for positive transformation. 


\section{Reference List}

About, I. 2012, 'Underclass Gypsies: An Historical Approach on Categorisation and Exclusion in France in the Nineteenth and Twentieth Centuries' in The Gypsy 'Menace': Populism and the New AntiGypsy Politics, (ed) M. Stewart. London: Hurst and Company: 95-114.

Albert, G. 2011, 'Forced Sterilization and Romani Women's Resistance in Central Europe,' Different Takes Online, available http://popdev.hampshire.edu/projects/dt/71 [Accessed $20 \mathrm{March} 2013$ ].

2012. 'Anti-Gypsyism and the Extreme-Right in the Czech Republic 2008-2011' in The Gypsy

'Menace': Populism and the New Anti-Gypsy Politics, (ed.) M. Stewart. Hurst and Company, London: $137-165$.

Amaré, M. 2010, 'France's “war on criminality” aside, Focus on Parisian Roma in "social insertion Villages",' Cafébabel Online, available: http://www.cafebabel.co.uk/article/34526/roma-socialinsertion-village-aubervilliers-france.html [Accessed 4 April 2013].

Amnesty International 2011, Briefing: Human Rights on the Margins - Roma in Europe Online, available: http://www.amnesty.org.uk/uploads/documents/doc_21165.pdf [Accessed 13 March 2012].

Barany, Z. 2002, The East European Gypsies: Regime Change, Marginality, and Ethnopolitics. Cambridge University Press, Cambridge.

Bednarikova, T. 2009, 'Anti-Roma wall through Slovak village provokes outcry,' The Telegraph, 25 November. Online, available: http://www.telegraph.co.uk/expat/expatnews/6650958/Anti-Romawall-through-Slovak-village-provokes-outcry.html [Accessed 12 December 2012].

Benesch, S. 2007-2008. 'Vile Crime or Inalienable Right: Defining Incitement to Genocide,' Virginia Journal of International Law, vol. 48, no 3: 485-528.

2011a, 'Contribution to OHCHR Initiative on Incitement to National, Racial, or Religious Hatred.' New York Office of the Special Adviser of the Secretary-General on the Prevention of Genocide, United Nations. Online, available: http://voicesthatpoison.files.wordpress.com/2012/01/beneschohchr1.pdf [Accesed 3 May 2013].

2011b, 'Election-Related Violence: The Role of Dangerous Speech,' Paper presented at the American Society of International Law Annual Meeting, Washington.

Benesch, S. 2012, 'Dangerous Speech: A Proposal to Prevent Group Violence,' Voices That Poison: Dangerous Speech Project, World Policy Institute, New York. Online, available: http://voicesthatpoison.org/proposed-guidelines-on-dangerous-speech/ [Accessed 3 May 2013].

Bikár, F. 2012, Czech Republic: Poll Shows Mostly Negative Views of Romani People, trans, G. Albert. Romea, Prague. Online, available: http://www.romea.cz/en/news/czech-republic-poll-showsmostly-negative-views-of-romani-people [Accessed 29 November 2012].

Brearley, M. 2001, 'The Persecution of Gypsies in Europe,' The American Behavioural Scientist, vol. 45, no. 5: 588-599.

Centre for Reproductive Rights and Poradňa 2002, The Slovak Government's Response to Reproductive Rights Violations against Romani Women: Analysis and Recommendations. Centre for Reproductive Rights, Poradňa, New York. Online, available: http://poradnaprava.sk/dok/report0603.pdf [Accessed 20 March 2013].

2003, Body and Soul: Forced Sterilizations and Other Assaults on Roma Reproductive Freedom in Slovakia. Centre for Reproductive Rights, Poradňa pre obcianske a l'udské práva, New York. Online, available: http://poradna-prava.sk/dok/bodyandsoul.pdf [Accessed 26 March 2013].

Cotler, I. 2011, 'Combating State-Sanctioned Incitement to Genocide: A Legal and Moral Imperative,' in Confronting Genocide, (eds) R. Provost and P. Akhavan. Springer, New York: 131-150.

Council of Europe 2012, Human Rights of Roma and Travellers in Europe. Commissioner for Human Rights, Council of Europe Publications, Strasbourg. Online, available: http://www.coe.int/t/commissioner/source/prems/prems79611_GBR_CouvHumanRightsOfRoma WEB.pdf [Accessed 27 November 2012].

Council of Europe \& Commissioner for Human Rights 2003, Recommendation of the Commissioner for Human Rights Concerning Certain Aspects of Law and Practice Relating to Sterilization of Women in the Slovak Republic. Council of Europe, Strasbourg. Online, available: https://wcd.coe.int/ViewDoc.jsp?id=979625 [Accessed 20 March 2013].

Crowe, D. M. 2003, 'The International and Historical Dimensions of Romani Migration in Central and Eastern Europe,' Nationalities Paper: The Journal of Nationalism and Ethnicity, vol 31, no 1: 8194.

Cryer, R. 2005, 'Incitement' in Encyclopedia of Genocide and Crimes Against Humanity. $2^{\text {nd }}$ vol., (ed) D. L. Shelton. Macmillan Reference USA, Detroit: 493-500. 
Czech Press Agency 2013, Czech Republic: Poll Shows only 4\% of Citizens Have Good Relations with Roma, trans. G. Albert. Romea, Prague. Online, available: http://romea.cz/en/news/czech/czechrepublic-poll-shows-only-4-of-citizens-have-good-relations-with-roma [Accessed 21 August 2013].

European Association for the Defense of Human Rights 2012, Roma People in Europe in the 21st Century: Violence, Exclusion, Insecurity, European Association for the Defense of Human Rights. Online, available:

http://www.aedh.eu/plugins/fckeditor/userfiles/file/Discriminations $\% 20$ et $\% 20$ droits $\% 20 \mathrm{des} \% 20 \mathrm{mi}$ norit\%C3\%A9s/AEDH\%20Roma\%20REPORT.pdf [Accessed 27 November 2012].

European Roma Rights Centre 2000, 'More Disturbing Events in Slovak Police Custody.' European Roma Rights Centre, Budapest. Online, available: http://www.errc.org/article/more-disturbingevents-in-slovak-police-custody/1043 [Accessed 23 April 2013]. 2003, Written Comments of the European Roma Rights Center Concerning the Slovak Republic For Consideration by the United Nations Human Rights Committee at its 78 th Session, European Roma Rights Centre, Budapest. Online, available: www.escr-net.org/usr_doc/m00000105.doc [Accessed 23 April 2013].

European Union Agency for Fundamental Rights 2009, Data in Focus Report: The Roma, The European Union Agency for Fundamental Rights (FRA), Luxembourg. Online, available:

http://fra.europa.eu/sites/default/files/fra_uploads/413-EU-MIDIS_ROMA_EN.pdf [Accessed 28 November 2012].

Evans, S. 2012, 'Merkel opens Roma Holocaust memorial in Berlin,' British Broadcast Corporation, 24 October. Online, available: http://www.bbc.co.uk/news/world-europe-20050780 [Accessed 17 December 2012].

Fings, K., Herbert H. \& Frank S. 1997, From "Race Science" to the Camps: The Gypsies during the Second World War. $1^{\text {st }}$ vol., trans. D. Kenrick. University of Hertfordshire Press, Hatfield.

Fraser, A. 1995. The Gypsies. 2nd edition. Blackwell, Oxford.

Gheorghe, N. \& Liégeois J. P. 1995, Roma/Gypsies: A European Minority, Minority Rights Group International, London.

Gil-Robles, A. 2006, Final Report by Mr Alvaro Gil-Robles, Commissioner for Human Rights, on the Human Rights Situation of the Roma, Sinti and Travellers in Europe for the attention of the Committee of Ministers and the Parliamentary Assembly, Office for the Commissioner for Human Rights, Council of Europe, Strasbourg. Online, available: https://wcd.coe.int/ViewDoc.jsp?id=962605\&Site=COE [Accessed 26 March 2013].

Glenny, M. 2012, 'Preface,' in The Gypsy 'Menace': Populism and the New Anti-Gypsy Politics, (ed) M Stewart. Hurst and Company, London: vii-xi.

Hammarberg, T. 2008, 'The Shameful History of anti-Gypsyism is Forgotten — and Repeated,' Strasbourg Council of Europe. Online, available:

http://www.coe.int/t/commissioner/Viewpoints/080818_en.asp [Accessed 5 December 2012].

Hancock, I. 1999, The Pariah Syndrome: An Account of Gypsy Slavery and Persecution. 2nd ed., Karoma Publishers, Michigan.

2002, We are the Romani People. University of Hertfordshire Press, Hatfield.

Helsinki Watch 1992, Struggling for Ethnic Identity: Czechoslovakia's Endangered Gypsies, Human Rights Watch, United States of America. Online, available:

http://www.hrw.org/legacy/reports/pdfs/c/czechrep/czech.928/czech928full.pdf [27 November 2012].

Hollinger, P. 2010, France Tries to Integrate Roma in Secure Sites. The Financial Times Limited, London, 27 August. Online, available: http://search.proquest.com/docview/748068200?accountid=14723 [Accessed 4 April 2013].

Holt, E. 2005, 'Roma Women Reveal that Forced Sterilisation Remains,' The Lancet, vol. 365, no. 9463 : 927-928.

Hübschmannova, M. 2003, 'Roma - Sub Ethnic Groups.' ROMBASE. Online, available: http://romani.uni-graz.at/rombase/cd/data/ethn/topics/data/names-pr.en.pdf [Accessed 2 November 2010].

Huttenbach, H. R. 1991, 'The Romani Pořajmos: The Nazi Genocide of Gypsies in Germany and Eastern Europe,' in The Gypsies of Eastern Europe, (eds) D. Crowe \& J. Kolsti. M. E. Sharpe, Inc, Armonk: 31-49.

JUDr. Otakar M. 2005, Final Statement of the Public Defender of Rights in the Matter of Sterilisations Performed in Contravention of the Law and Proposed Remedial Measures. Public Defender of Rights, Brno.

Kelso, M. 2007, 'Hidden History: Perceptions of the Romani Holocaust in Romania Viewed Through Contemporary Race Relations,' The Anthropology of East Europe Review, vol. 25, no. 2: 44-61. 
2013, “"And Roma Were Victims, too.” The Romani Genocide and Holocaust Education in Romania,' Intercultural Education, vol. 24, no. 1-2: 61-78.

Kenrick, D. \& Grattan P. 1972, The Destiny of Europe's Gypsies. Sussex University Press, London. Lacatus, G. 2011, 'A Romanian Mayor Wants to Build a Wall to Isolate the Blocks Inhabited by Roma,' Roma Transitions. Online, available: http://www.romatransitions.org/a-romanian-mayor-wants-tobuild-a-wall-to-isolate-the-blocks-inhabited-by-roma/ [Accessed 6 May 2013].

2012, 'Romanian Mayor Moves Hundreds of Roma to a Decommissioned Chemical Factory,' Roma Transitions. Online, available: http://www.romatransitions.org/romanian-mayor-moveshundreds-of-roma-to-a-decommissioned-chemical-factory/ [Accessed 18 December 2012].

Land, T. 2008, 'Coping with the Persecution of the Roma in Slovakia,' Contemporary Review, vol. 290, no. 1688: 60-63.

Liégeois, J. P. 1994, Roma, Gypsies, Travellers. Council of Europe, Strasbourg.

Magyari-Vincze, E. 2006a, Romani Women's Reproductive Health as a Human Rights Issue in Romania. Central European University Centre for Policy Studies and Open Society Institute, Budapest.

2006b, Social Exclusion at the Crossroads of Gender, Ethnicity and Class: A View of Romani Women's Reproductive Health. Central European University Centre for Policy Studies and Open Society Institute, Budapest.

Mayall, D. 2004, Gypsy Identities 1500-2000: From Egipcyans to Moon-men to the Ethnic Romany. Routledge, New York.

McGarry, A. 2010, Who Speaks for the Roma? Political Representation of a Trasnational Minority Community. Continuum, New York.

Ministry of Health of the Slovak Republic 2003, Press Release: Report on the findings of the investigation of the State Control Section at the Ministry of Health of the Slovak Republic. Ministry of Health of the Slovak Republic, Bratislavia. Online, available:

http://www.health.gov.sk/redsys/rsi.nsf/0/57A619F14F13A70BC1256CEE0053706C?OpenDocum ent [Accessed 23 April 2013].

National Party 2009, Klip Národni strany / Czech National Party ad for election to European Parlament 2009 (sic). National Party, Prague. Online, available: http://www.youtube.com/watch?v=zqiDgZtfQw [Accessed 3 May 2013].

Nicolae, V. 2002, 'Romanian Gypsies,' Peace Review: A Journal of Social Justice, vol. 14, no. 4: 385393.

2005, 'Who Now Remembers the Roma?,' Index on Censorship, vol. 34, no. 2: 65-67.

2009, 'The Enemy within: Roma, the Media and Hate Speech,' Eurozine. Online, available: http://www.eurozine.com/articles/2009-03-20-nicolae-en.html [Accessed 20 March 2013].

O’Nions, H. 2011, 'Roma Expulsions and Discrimination: The Elephant in Brussels,' European Journal of Migration and Law, vol. 13, no. 4: 361-388.

Open Society Foundations 2011, Against Her Will: Forced and Coerced Sterilization of Women Worldwide. Open Society Foundations, New York. Online, available:

http://www.opensocietyfoundations.org/sites/default/files/against-her-will-20111003.pdf [Accessed 22 November 2012].

Parekh, B. 2006, 'Hate Speech: Is There a Case for Banning?,' Public Policy Research, vol. 12, no. 4: 213-223.

Perlez, J. 1998, Usti nad Labem Journal; A Wall Not Yet Built Casts the Shadow of Racism. The New York Times, 2 July. Online, available: http://www.nytimes.com/1998/07/02/world/usti-nad-labemjournal-a-wall-not-yet-built-casts-the-shadow-of-racism.html [Accessed 12 December 2012].

Petrova, D. 2003, 'The Roma: Between a Myth and the Future,' Social Research, vol. 70, no. 1: 111-162.

Polak, K. 2013, 'Teaching about the Genocide of the Roma and Sinti during the Holocaust: Chances and Challenges in Europe Today,' Intercultural Education, vol. 24, no. 1-2: 79-92.

Powell, C. 2011, Barbaric Civilization: A Critical Sociology of Genocide. McGill-Queen's University Press, Montreal.

Scicluna, Henry. 2007, 'Anti-Romani Speech in Europe's Public Space: The Mechanism of Hate Speech,' European Roma Rights Centre, Budapest. Online, available: http://www.errc.org/cikk.php?cikk=2912 [Accessed 28 November 2012].

Sigona, N. 2005, "Locating 'The Gypsy Problem.' The Roma in Italy: Stereotyping, Labelling and 'Nomad Camps',' Journal of Ethnic and Migration Studies, vol. 31, no. 4: 741-756.

2011, 'The Governance of Romani People in Italy: Discourse, Policy and Practice,' Journal of Modern Italian Studies, vol. 16, no. 5: 590-606.

Sridhar, C. R. 2006, 'The Romani Holocaust,' Economic and Political Weekly, vol. 41, no. 33: 35693571 . 
Staff of the U.S. Commission on Security and Cooperation in Europe 2006, Accountability and Impunity: Investigations Into Sterilisations Without Informed Consent in the Czech Republic and Slovakia. Commission on Security and Cooperation in Europe, Washington D.C.

Stewart, M, (ed.) 2012, The Gypsy 'Menace': Populism and the New Anti-Gypsy Politics. Hurst and Company, London.

Thomas, J. 2006, 'State Dept.: Coercive Sterilization of Romani Women Examined at Hearing.' US Fed News Service, August 16.

Timmermann, W. 2008, 'Counteracting Hate Speech as a Way of Preventing Genocidal Violence,' Genocide Studies and Prevention, vol. 3, no. 3: 353-374.

United Nations 1948, 'Convention on the Prevention and Punishment of the Crime of Genocide, Paris, 9 December 1948.' United Nations. Online, available: http://treaties.un.org/Pages/ViewDetails.aspx?src=IND\&mtdsg_no=IV-1\&chapter=4\&lang=en [Accessed 11 May 2012].

United Nations Human Rights Committee 2011, 'Consideration of Reports Submitted by States Parties under Article 40 of the Covenant: Concluding Observations of the Human Rights CommitteeSlovakia,' United Nations Human Rights Committee, New York. Online, available: http://daccessdds-ny.un.org/doc/UNDOC/GEN/G11/422/77/PDF/G1142277.pdf?OpenElement [Accessed 12 June 2013].

United States Holocaust Memorial Museum 2001. 'Sinti \& Roma: Victims of the Nazi Era.' United States Holocaust Memorial Museum, Washington, DC. Online, available:

http://www.ushmm.org/education/resource/roma/RomaSBklt.pdf [Accessed 30 March 2012].

2011, 'Genocide of European Roma (Gypsies), 1939-1945.' United States Holocaust Memorial Museum, Washington, DC. Online, available:

http://www.ushmm.org/wlc/en/?ModuleId=10005143 [Accessed 30 March 2012].

Van der Stoel, M. 2000, Report on the Situation of Roma and Sinti in the OSCE Area. Organization for Security and Co-operation in Europe, The Hague. Online, available: http://www.osce.org/hcnm/42063 [Accessed 28 November 2012].

Wallenstein, J. 2001, 'Punishing Words: An Analysis of the Necessity of the Element of Causation in Prosecutions for Incitement to Genocide,' Stanford Law Review, vol. 54, no. 2: 351-398.

Wippermann, W. 2006, 'Compensation Withheld: The Denial of Reparations to the Sinti and Roma,' in The Final Chapter: The Gypsies during the Second World War. $3^{\text {rd }}$ Vol., (ed) D. Kenrick. University of Hartfordshire Press, Hatfield: 171-177.

Woodcock, S. 2007a, 'Romania and EUrope: Roma, Roma and Țingani as Sites for the Contestation of Ethno-national Identities,' Patterns of Prejudice, vol. 41, no. 5: 493-515. 2007b, 'Romanian Romani Resistance to Genocide in the Matrix of the Țigan Other,' The Anthropology of East Europe Review, vol. 25, no. 2: 28-43.

Zoon, I. 2001, On the Margins: Slovakia: Roma and Public Services in Slovakia. Open Society Institute, New York. Online, available:

http://www.eurac.edu/en/research/institutes/imr/Documents/Zoon_RomaandPublicServicesinSlova kia_2001.pdf [Accessed 9 April 2013]. 